\title{
РОЗВИТОК ЕМОЦІЙНОЇ СФЕРИ ДЕВІАНТНИХ ПІДЛІТКІВ ЗАСОБАМИ МУЗИКИ
}

Сидоренко Т. Д. Розвиток емоційної сфери девіантних підлітків засобами музики.

У статті обгрунтовано можливість використання музики як засобу розвитку емоційної сфери девіантних підлітків, запропоновано умови, які, на думку автора, необхідні для здійснення емоційної реабілітації підлітків засобами музики.

Ключові слова: підлітковий вік, девіантна поведінка, девіантний підліток, відхилення поведінки, емоційна сфера.

Сидоренко Т. Д. Развитие эмоциональной сферы девиантных подростков средствами музыки.

В статье обоснована возможность использования музыки как средства развития эмоциональной сферы девиантных подростков, предложены условия, которые, по мнению автора, необходимы для осуществления эмоциональной реабилитации подростков средствами музыки.

Ключевые слова: подростковый возраст, девиантное поведение, девиантный подросток, отклонение поведения, эмоциональная сфера.

Sidorenko T. D. Development of emotional sphere of teenagers with deviant behavior by means of music.

The article describes the possibility of using music as a means to develop the emotional sphere deviant adolescents, offered conditions which, in the author's opinion are necessary for the implementation of emotional rehabilitation of teenagers by means of music.

Key words: ad olescence, deviant behavior, teenagers with deviant behavior, deviation behavior, emotional sphere.

XXI століття поставило гострі запитання щодо здібностей людини, іï готовності адаптуватися в умовах зростаючої складності світу, високого динамізму всіх суспільних процесів, непередбачуваності глобальних змін. Поглиблення кризового стану одночасно в трьох сферах життєдіяльності - духовній, соціальній і матеріальній, спричинила глибокі зрушення у світосприйманні, орієнтації молоді у галузях культури, професійного самовизначення.

В умовах економічної нестабільності в країні, відсутності впевненості в майбутньому посилюють труднощі визначення сенсу життя підростаючого покоління, що сприяє виникненню й засвоєнню асоціальних та аморальних норм поведінки, втраті психічної стійкості до впливу негативних факторів у соціально-інформаційній і міжособистісній сферах, зростанню девіантних форм поведінки у підлітковому середовищі.

Підлітковий вік - це час становлення характеру. Саме в цей період вплив середовища, найближчого оточення виявляється з величезною силою. Зовнішній вияв складного процесу становлення характеру виявляється в поведінці підлітка, яка часто пов'язана з відхиленнями в цьому процесі. У зв'язку з цим досить часто виникають ускладнення психологічного розвитку, значна частина яких є лише відхиленням від норми, а не психологічним захворюванням.

Нерідко емоційний розвиток дітей буває порушеним, а їх поведінка негативною. Оздоровлення емоційної сфери, на думку Е. Абдуліна, сприяє виникненню у підлітків почуття власних цінностей та самоповаги, а це в свою чергу «сприяє виникненню внутрішніх ресурсів, необхідних для того, щоб не просто захищатися від щоденних проблем, але й керувати ними» [1, c. 211].

Метою статті є виявлення можливості розвитку емоційної сфери девіантних підлітків засобами музики в межах освітнього процесу.

Психологічним аспектам становлення особистості підлітка присвячено безліч досліджень науковців (С. Бабенко, Е. Еріксон, О. Ідобаєва, Є. Ільїн, В. Казанська, П. Лафреньє, В. Оржевська, А. Подільський, Л. Регуш, О. Реан та ін.). Вони доводять, що образ «Я» в цей час нестабільний, менш позитивний порівняно з молодшим шкільним віком, емоційна сфера зазнає значних змін.

Емоції поділяються на позитивні (радість, інтерес тощо) й негативні (гнів, ненависть, страх тощо). Усі ці емоційні переживання властиві людині, оскільки вони допомагають керувати 
своєю поведінкою, наповнюють життя сенсом, утворюють у сукупності емоційну сферу особистості. Але будь-які емоції можуть перетворитися з корисних, позитивних на шкідливі й негативні (агресія, образа, заздрість тощо ), унаслідок чого поведінка підлітка не відповідає загальноприйнятим нормам, відбувається порушення цих норм, що й викликає проблему. Така поведінка називається девіантною, ії корекція завжди була важливою у педагогіці, психології, але останнім часом набула масового характеру.

Нині у представників педагогічної, психологічної, медичної літератури відсутнє єдине, усталене поняття «відхилення поведінки».

Ми погоджуємося з думкою В.Оржевської щодо визначення девіантної поведінка, а саме: «...Поведінка, що суперечить прийнятим у суспільстві правовим або моральним нормам» $[6, \mathrm{c}$. 27]. Ця поведінка, що призводить до поглиблення дезадаптації, є результатом асоціального розвитку особистості, впливу на неї несприятливих соціальних ситуацій, накладання негативних соціальних чинників на «вразливі місця» особистості.

Значна частина поведінкових порушень здійснюється підлітками в стані низького рівня розвитку психічної діяльності. Оскільки це так, то необхідно сприяти підвищенню рівня розвитку психічної діяльності, психічних процесів, свідомості і самосвідомості, які найбільше виявляються в самооцінці підлітка та його соціальному статусі в колективі однолітків.

Ми виходимо 3 переконань щодо можливостей позитивного впливу музики на розвиток емоційної сфери девіантних підлітків. Це зумовлюється ії багатогранністю, яка має безпосередній вплив на несвідомі шари психіки, впливає на почуття людини, проникаючи крізь захисні механізми свідомості; впливає на стан нервової системи (заспокоює, розслаблює чи, навпаки, розбурхує, збуджує), викликає різні емоційні стани, від спокою та гармонії до неспокою, пригніченості або агресії).

Проблемою впливу музики на розвиток людини опікувались такі сучасні науковці, як: Е. Абдулін, В. Зубарев, І. Назаренко, І. Климук, О. Сапожник, О. Середюк та ін. Але аспект розвитку емоційної сфери девіантних підлітків засобами музики досліджений недостатньо.

Музика має велику силу та цілющі властивості, створює позитивну релаксаційну атмосферу під час уроків з різних дисциплін, впливає на сердечний ритм, пульс і кров'яний тиск. Ритм серцевих скорочень можна регулювати за допомогою звуків і музики. Серцебиття реагує на чистоту, ритм і гучність, які можуть прискорювати чи уповільнювати серцеві ритми. Чим швидша музика, тим швидше б'ється серце; чим повільніша музика, тим повільніший ритм серцевих скорочень.

Емоційна сфера девіантних підлітків має свої особливості. Саме музика здатна викликати в них сильні переживання, допомогти їм зрозуміти свої емоції, а також стимулювати у них процеси творчості, уяви, сприйняття.

Важливим етапом у роботі з девіантними підлітками може стати й уміла організація спільного співу. Застосування цього методу сприяє також зняттю внутрішнього психологічного дискомфорту, розвитку почуття самоактуалізації підлітків, водночас викликати почуття згуртованості, підтримки та емпатії. Відомо, що музично-ритмічна активізація сприяє пожвавленню психомоторики, поліпшенню поведінкових характеристик, зняття скутості рухів у підлітків, а також розвиває їх ритмічне і слухове сприйняття.

У збудливих осіб рухові вправи під музику вивільняють накопичену агресивність i роздратування. Для цих цілей краще обрати невеликі уривки з сучасних танцювальних мелодій, що мають чіткий ритм. Своєрідним рішенням до розв'язання цього питання можуть бути дискотеки.

Здійснивши спостереження за підлітками на уроках музики в загальноосвітніх школах та на позакласних виховних заходах, можемо констатувати, що на уроці музики можна розв'язувати не тільки освітні, розвивальні, виховні, але й корекційні завдання, а саме: врахування психологічних особливостей девіантних підлітків, що зумовлює необхідність пошуку більш глибокого у порівнянні $з$ традиційною методикою розвитку емоційної сфери, а саме: психологічному впливу музики на емоційну сферу підлітка.

На нашу думку, розвиваючи емоційну сферу девіантного підлітка важливо встановити потрібний «тон» взаємин, ураховуючи те, що ці підлітки, як правило, мають негативний досвід спілкування з учителями, будь-яка допомога з боку дорослих ними не тільки не приймається, але й категорично відхиляється. Будь-яку спробу втручання у свій внутрішній світ учні 
вважають небезпечною й намагаються всіма силами захиститися, демонструючи замкнутість, агресивність, неповагу, ворожість, брехливість.

Успіх окресленого виду роботи забезпечується особливою методикою проведення уроків музики. Одним із таких видів $є$ вибір жанру музики, який би позитивно впливав на розвиток емоційної сфери підлітка.

Так, у межах кожного жанру виокремлюють різноманіття стилів, кожний із яких має безпосередній вплив на емоційну сферу. Деякі з них активні і несуть енергію, інші пасивні, релаксаційні. Швидкий джаз може заставити кров активніше циркулювати, посилити пульс і викликати надмірне виділення гормонів, тоді як повільна, мелодійна, релаксаційна мелодія може знизити кров'яний тиск, перевести мозок в режим альфа-хвиль і віднести нас від проблем.

Повільна музика в стилі бароко (Бах, Гендель та ін.) дає відчуття стійкості, порядку, безпеки і створює духовне середовище.

Класична музика (Бетховен, Вівальді, Ліст, Моцарт) відрізняється ясністю, елегантністю і прозорістю. Вона здатна підвищувати концентрацію, пам'ять і просторове сприйняття.

Музика романтизму (Шопен, Шуберт, Шуман, Чайковський) підкреслює виразність і чуттєвість, часто пробуджує індивідуалізм. Ї̈ краще за все використовувати для того, щоб активізувати симпатію, пристрасть і любов.

Музика імпресіоністів (Равель, Дебюссі) побудована на музичних настроях і враженнях. Вона викликає приємні образи, може збуджувати творчі імпульси.

Танцювальні форми, в основі яких лежать виразні африканські мелодії, можуть підняти настрій і надихнути, принести радість, розсіяти сум, загострити гумор та іронію, підвищити комунікативність.

Поп-музика, а також народні мелодії провокують рухи тіла, створюють відчуття благополуччя, спокою.

Рок-музика може пробуджувати відчуття, стимулювати активні рухи, зняти напругу, послабити біль і знизити неприємний ефект гучних і різких звуків, присутніх в навколишньому середовищі. Ця музика також здатна створити напругу, викликати дисонанс, стрес і біль в організмі.

Спокійна фонова музика чи сучасні оркестрові твори, у яких немає чітких ритмів, посилюють стан розслабленої готовності.

Музика у стилі панк, реп, хіп-хоп може збуджувати, підвищувати активність.

Релігійна й обрядова музика, барабани шаманів, церковні гімни, храмова музика можуть сприяти досягненню стану заспокоєння.

Кожен підліток має улюблений жанр музики, який впливає на його духовний світ найбільш позитивно. Масовим попитом користується музика великих частот (поп- та рок-музика). При цьому і класичний жанр має своє місце в молодіжній аудиторії. Сприйняття музики викликає в організмі підлітка фізіологічні зміни (підсилює метаболізм, стабілізує мускульну енергію, змінює кров'яний тиск, емоції). Завдяки експресивності, ритміці, музика через тілесні рухи, танці дозволяє підліткам знижувати емоційні реакції: хвилювання, афекти, неусвідомлені переживання.

Музика занурює підлітків у залежність від висоти, сили, темпу і створює для них складну гаму слухових, тілесних відчуттів та соціальних переживань. Цікавими виявилися експресдослідження, які проводилися науковцями у великих рок-залах Японії. Під час опитування підлітки стверджували, що під час сприйняття рок-музики, вони отримують значне за силою задоволення - «кайф» i, занурюючись у музику, втрачають реалії буття і навіть самих себе. Те, що відбувається з підлітками, захопленими рок-музикою, - це явище, що демонструє початковий рівень сприйняття музики. Він пов'язаний з переживаннями ритму і великих частот музичних звуків у сполученні з тілесними рухами. Це явище вікового характеру, а тому в подальшому, в дорослому віці, люди меншою мірою тяжіють до цього жанру музики.

Саме ця вікова категорія прагне сприймати музику на вищому абсолютному порозі чутливості, який буде ефективним за створення таких умов:

- облаштування музичного класу, використання технічних засобів навчання;

- особистість учителя-музиканта, який повинен виконувати роль «девіантолога»;

- підбір музичного матеріалу, який контрастує з тривогою, збудженістю;

- використання вокально-хорової музики, яка відповідає характеру прослуханих перед цим інструментальних творів; 
- уміння вчителя змінити план уроку, якщо цього вимагає конкретна ситуація;

- використання різноманітних форм уроків: урок-концерт, урок-психодрама, урок-фантазія.

Аналіз спостережень дозволяє говорити про те, що за створення вказаних умов для занять підлітки у змозі за короткий проміжок часу почати емоційно відгукуватися на художньо повноцінну музику, навчитися відкривати для себе емоційну виразність музичного твору, усвідомлювати емоційне співпереживання.

Проведена робота доводить важливість цілеспрямованих музичних занять для оздоровлення емоційної сфери девіантних підлітків, збагачення їхньої духовного світу.

\section{Література}

1. Абдуллин Э. Б. Методологическая культура педагога-музыканта [учеб. пособ. для студ. высших учеб. заведений] / Э. Б. Абдуллин. - М.: Изд. центр «Академия», 2002. - 272 с. 2. Баранов В. В. Дослідження автобіографії девіантного підлітка як один з прийомів виявлення його десоціалізації / В. В. Баранов, І. О. Похлебна // Практична психологія і соціальна робота. - 2001. - № 9. 3. Денисов І. Г. Біологічні чинники девіантної поведінки та профілактика їх виявлень у вихованні громадської спрямованості у підлітковому віці / І. Г. Денисов // Постметодика. - 2002. - №7-8 (4546). - С. 207-212. 4. Клейберг Ю. А. Психология девиантного поведения / Ю. А. Клейберг. - М., 2001. - 454 с. 5. Змановская Е. В. Девиантология: психология отклоняющегося поведения: [учеб. пособ. для студ. высш. учеб. заведений] / Е. В. Змановская. - М. : Изд. Центр «Академия», 2003. 288 с. 6. Оржеховська В. М. Профілактика правопорушень серед неповнолітніх: [навч.-метод. посіб.] / В.М. Оржеховська. - К.: КВІАН, 1996. -352 с.

УДК 373.5.016:91

Світлана Тросюк

\section{КОМПЕТЕНТНІСНИЙ ПІДХІД У НАВЧАННІ ГЕОГРАФІЇ УЧНІВ ОСНОВНОЇ ШКОЛИ}

Тросюк С. Д. Компетентнісний підхід у навчанні географії учнів основної школи.

У статті розкрито сутнісні характеристики компетентнісного підходу у навчанні географії учнів основної школи. Подано вичерпну характеристику географічних компетентностей учнів основної школи у процесі вивчення географії. Розкрито взаємозв'язок міри упровадження компетентнісного підходу у навчанні географії учнів основної школи і рівнями сформованості географічних компетентностей у процесі вивчення навчальних предметів природничого циклу.

Ключові слова: компетентнісний підхід, учні основної школи, навчання географії в основній школі, географічні компетентності.

Тросюк С. Д. Компетентностній поход в обучении географии учащихся основной школы.

В статье раскрыты сущностные характеристики компетентностного подхода в обучении географии учеников основной школы. Приведена исчерпывающая характеристика географических компетентностей учеников основной школы в процессе изучения географии. Раскрыта взаимосвязь степени реализации компетентностного подхода в обучении географии учеников основной школы и уровнями сформированости географических компетеностей в процессе изучения учебных предметов природоведческого цикла.

Ключевые слова: компетеностный подход, ученики основной школы, обучение географии в основной школе, географические компетености.

Trosyuk S. D. Competence approach in teaching of geography primary school students.

The article reveals the essential characteristics of competence-based approach in teaching students the basic geography of the school. Given an exhaustive description of geographical competences elementary school students in the study of geography. A reconciliation of the degree of implementation kompetenostnogo approach to learning geography primary school pupils and level of development of geographic competence in the study of academic subjects Natural History cycle.

Key words: competence approach, primary school pupils, teaching geography in elementary school, geographic competence.

Нині в теорії вітчизняної географічної науки та теорії соціальної географії відбувається перегляд і переосмислення змісту, форм, методів і принципів розроблення нових підходів до формування географічних компетентностей. Цей процес зумовлює необхідність у створенні 